\title{
О.С. Кривопустов
}

\section{ДОСЛІДЖЕННЯ ПРОГЕСТЕРОН ІНДУКОВАНОГО БЛОКУЮЧОГО ФАКТОРА ПРИ ЛІКУВАННІ ЖІНОК ІЗ ЗАГРОЗЛИВИМ АБОРТОМ 3 УРАХУВАННЯМ ПОЛІМОРФІЗМУ ГЕНА РЕЦЕПТОРА ПРОГЕСТЕРОНУ}

\author{
Національний медичний університет ім. О.О. Богомольия \\ кафедра акушерства і гінекології № 2 \\ (зав. - д. мед. н., проф. О.П. Гнатко) \\ вул. П. Запорожия, 26-а, Київ, 02125, Україна \\ O.O. Bohomolets National Medical University \\ Department of Obstetrics and Gynecology N 2 \\ P. Zaporozhetsa Str., 26-a, Kyiv, 02125, Ukraine \\ e-mail:kryvopustov@gmail.com
}

\begin{abstract}
Ключові слова: загрозливий аборт, поліморфізм гена рецеептора прогестерону, прогестерон індукований блокуючий фактор, терапія препаратом натурального мікронізованого прогестерону

Key words: threatened abortion, progesterone receptor gene polymorphism, progesterone induced blocking factor, natural micronized progesterone therapy
\end{abstract}

Реферат. Исследование прогестерон индуцированного блокирующего фактора при лечении женщин с угрожающим абортом с учетом полиморфизма гена рецептора прогестерона. Кривопустов А.С. Актуальной медико-социальной проблемой современного акушерства является угрожающий аборт. В его лечении используются аналоги прогестерона. Активизация рецепторов прогестерона индуцирует выработку антиабортивного протеина - прогестерон индуцированного блокирующего фактора (ПИБФ). Проанализирована динамика ПИБФ у 28 пациенток с диагнозом угрожающего аборта. Женщинам проводилась терапия препаратом натурального микронизированного прогестерона в зависимости от особенностей клинического течения и однонуклеотидного полиморфизма гена рецеептора прогестерона rs590688. Определяли количественное содержание ПИБФ в моче у беременных с угрожаюшим абортом, именно рост содержания данного фактора ассоциируется с пролонгаџией беременности. На момент начала терапии концентрация

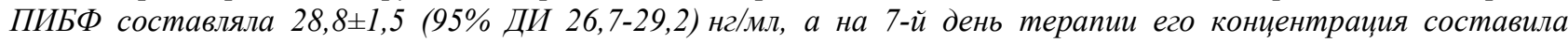
29,4士0,1 (95\% ДИ 29,2-29,5) нг/мл. Увеличение уровня ПИБФ достигло степени статистической значимости $(T-W=15,0 ; p<0,001)$. У 27 (96,4\%) пациенток, которые выносили беременность, наблюдалось увеличение уровня ПИБФ, у 1 (3,6\%) пациентки произошел самопроизвольный выкидыш на 9-й день лечения. Именно у нее наблюдалось снижение концентрациии ПИБФ в моче с 29,18 нг/мл на момент поступления в клинику до 28,58 нг/мл на 7-й день терапии. Исследование прогестерон индуциированного блокирующего фактора можно рассматривать в качестве дополнительного лабораторного метода контроля терапии препаратом прогестерона у женщин с угрожающим абортом в профильных научно ориентированных учреждениях.

\begin{abstract}
Study of progesterone-induced blocking factor in the treatment of women with threatening abortion, taking into account the polymorphism of the progesterone receptor gene. Kryvopustov O.S. Actual medical and social problem of modern obstetrics is threatening abortion. In its treatment, analogues of progesterone are used. Activation of progesterone receptors induces the production of anti-abortive protein-progesterone-induced blocking factor (PIBF). The dynamics of PIBF in 28 patients with the diagnosis of threatening abortion was analyzed. Women were treated by natural micronized progesterone depending on the features of the clinical course and single nucleotide polymorphism of the progesterone receptor gene rs590688. The quantitative content of PIBF in urine in pregnant women with threatening abortion was determined, namely, the increase in the content of this factor is associated with the prolongation of pregnancy. At the time of initiation of therapy, the concentration of PIBP was $28.8 \pm 1.5(95 \%$ CI 26.7-29.2) $\mathrm{ng} / \mathrm{ml}$, and on the 7 th day of therapy its concentration was $29.4 \pm 0.1$ (95\% CI 29.2-29.5) $\mathrm{ng} / \mathrm{ml}$. The increase in PIBF has reached a degree of statistical significance (T-W=15.0, p<0.001). In 27 (96.4\%) patients who were pregnant, PIBP levels increased, 1 (3.6\%) patient had spontaneous miscarriage on the 9th day of treatment. She had a decrease in concentration of PIBF in urine from $29.18 \mathrm{ng} / \mathrm{ml}$ at the time of admission to the hospital to $28.58 \mathrm{ng} / \mathrm{ml} \mathrm{on}$ the 7th day of therapy. The study of progesterone-induced-blocking factor can be considered as an additional laboratory method of controlling progesterone therapy in women with threatening abortion in specialized research institutions.
\end{abstract}


Актуальною медико-соціальною проблемою сучасного акушерства є загрозливий аборт [1]. Відомо, що в забезпеченні репродуктивної функції жінки, імплантації зиготи, маткового спокою протягом вагітності відіграє вкрай важливу роль прогестерон [4]. Дія прогестерону реалізується через активацію рецепторів прогестерону, а ці рецептори кодуються геном рецептора прогестерону, який знаходиться на хромосомі 11q2223 [9]. Ця рецепторна відповідь на прогестерон може залежати від генетичних варіантів, наприклад, однонуклеотидного поліморфізму гена рецептора прогестерону [7].

На сьогодні задля патогенетичного лікування загрозливого аборту в жінок використовуються препарати прогестерону. Їх використання $\epsilon$ ефективним та безпечним у лікуванні загрози викидня, за даними Кокранівського огляду та Європейського клубу прогестинів [11]. Важливо, що активізація рецепторів прогестерону індукує вироблення антиабортивного протеїну - прогестерон індукованого блокуючого фактору (ПІБФ). Це зумовлює імунологічну толерантність за рахунок переходу від Th1 відповіді до Th2, що забезпечує прогресування вагітності $[5,8]$.

МАТЕРІАЛИ ТА МЕТОДИ ДОСЛІДЖЕНЬ

Було проаналізовано динаміку ПІБФ у 28 пацієнток 3 діагнозом загрозливий аборт. Критерії включення пацієнток до дослідження: вік від 18 років до 45 років включно; гестаційний термін цієї вагітності 8-16 тижнів; одноплідна вагітність; наявність клінічних ознак загрозливого аборту; наявність інформованої письмової згоди. Жінкам проводилась терапія препаратом натурального мікронізованого прогестерону залежно від особливостей клінічного перебігу та SNP (однонуклеотидного поліморфізму) PGR (гена рецептора прогестерону) rs590688 [2, 3].

Пацієнтки із загрозливим абортом були розподілені на 2 підгрупи. До першої підгрупи було включено 15 жінок 3 больовим синдромом за ЦРШ (цифровою рейтинговою шкалою) до 4 балів включно, в яких були відсутні або мали місце помірні кров'янисті виділення зі статевих шляхів, котрі мали гетерозиготу $\mathrm{C} / \mathrm{G}$ або мінорну гомозиготу $\mathrm{G} / \mathrm{G}$ за поліморфізмом PGR rs590688 $(\mathrm{C} / \mathrm{G})$. Для них доза натурального мікронізованого прогестерону становила 300 мг на добу, а саме по 100 мг 3 рази на добу перорально.

Другу підгрупу склали 13 жінок, які мали больовий синдромом за ЦРШ понад 4 бали та/або в яких були наявні рясні кров'янисті виділення зі статевих шляхів та/або які мали мажорну гомозиготу $\mathrm{C} / \mathrm{C}$ за поліморфізмом PGR rs590688 (C/G). Для них доза натурального мік- ронізованого прогестерону становила 600 мг на добу, а саме по 200 мг 3 рази на добу перорально. Лікування продовжувалося в обраній дозі 7 днів після досягнення ефекту з поступовим зниженням дози зазначеного препарату на 100 мг на тиждень.

Оцінка клінічної ефективності терапії прогестероном здійснювалася шляхом аналізу швидкості досягнення клінічного ефекту (припинення болю, зникнення кров'янистих виділень) та загальної тривалості лікування. Ефектом лікування вважалося зникнення болю, відсутність кров'янистих виділень зі статевих шляхів та прогресування вагітності.

Використовувалися такі методи дослідження: оцінка даних анамнезу, анкетування (оцінка болю за ЦРШ), клінічні, лабораторні, молекулярно-генетичні (визначення PGR rs590688), інструментальні (ультразвукове дослідження органів малого тазу). Пацієнткам проводилось дворазове визначення рівня прогестерону в крові та прогестерон індукованого блокуючого фактора в сечі з метою динамічного лабораторного контролю ефективності терапії препаратом прогестерону.

Концентрацію прогестерон індукованого блокуючого фактора визначали методом імуноферментного аналізу (Human PIBF ELISA Kit) відповідно до протоколу фірми-розробника (Elabscienсе, США). Принцип методу базується на специфічній реакції зв'язування антигена 3 антитілом, коли антитіло з'єднується із ферментом та додається до зразка з антигеном.

Статистична обробка отриманих результатів здійснювалася за допомогою статистичного пакету SPSS, версія 22, з використанням статистичного середовища R, версія 3.2.

\section{РЕЗУЛЬТАТИ ТА ЇХ ОБГОВОРЕННЯ}

При надходженні до гінекологічного відділення біль внизу живота спостерігався у 26 $(92,6 \%)$ пацієнток, кров'янисті виділення - у 15 $(53,6 \%)$ пацієнток. Виділення 3 піхви у 13 $(46,4 \%)$ осіб були слизовими в межах норми. У 9 $(32,1 \%)$ пацієнток раніше протягом цієї вагітності були явища загрози аборту, вони отримували терапію препаратом прогестерону. Відомостей щодо індивідуальної непереносимості препаратів прогестерону не було в жодному випадку.

Сімейний анамнез у 7 (25\%) пацієнток був обтяжений передчасними пологами та/або самовільним викиднем у матерів та/або бабусь в анамнезі. Жодна професійна шкідливість не була виявлена в пацієнток, включених до дослідження. При з'ясуванні можливих шкідливих звичок, таких як тютюнопаління, алкоголізм, наркоманія, 
3 (10,7\%) жінки зазначили наявність курця в сім’ї та 1 (3,6\%) жінка палила до вагітності й продовжувала палити під час вагітності. Переважна більшість жінок, а саме 27 (96,4\%) осіб, мали вищу освіту або неповну вищу освіту.

Менархе відбулося в середньому в $13,0 \pm 0,6$ року. Протягом 2-х років у всіх пацієнток відзначено встановлення регулярної менструальної функції, середня тривалість циклу становила

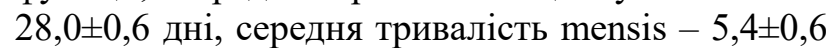
дня, об'єм крововтрати не перевищував 80 мл, міжменструальні кровотечі не спостерігались. Початок статевого життя в середньому становив у 18,9 $\pm 0,7$ року. Більшість жінок - 16 (57,1\%) до вагітності використовувала природній метод контрацепції, 8 (28,6\%) використовували бар'єрний метод та 4 (14,3\%) застосовували гормональну контрацепцію. Переважна більшість, а саме 25 (89,3\%) пацієнток, були у шлюбі, 26 (92,9\%) зазначали стан здоров'я батька майбутньої дитини як «здоровий».

7 (25\%) пацієнток очікували на другу дитину, $2(7,1 \%)$ - на третю дитину, $1(3,6 \%)$ - на шосту дитину, а решта, тобто 18 (64,3\%) жінок, очікували на першу дитину. 12 (42,9\%) пацієнток мали викидень в анамнезі. Серед гінекологічних захворювань найчастіше відзначали сквамозні інтраепітеліальні порушення епітелію шийки матки низького ступеня вираженості - 8 (28,6\%) пацієнток та функціональні кісти яєчників - у 2 (7,1\%) жінок.

При проведенні гінекологічного обстеження в усіх пацієнток зовнішні статеві органи були розвинуті правильно та не мали ознак запалення; при проведенні огляду в дзеркалах зовнішне вічко шийки матки у всіх пацієнток було зачинене; у 15 (53,6\%) пацієнток визначалися кров’янисті виділення 3 цервікального каналу. Розміри матки в усіх пацієнток відповідали термінам вагітності, не відмічалося вкорочення вагінальної частини шийки матки. Ехографічно у всіх пацієнток було визначено наявність серцевих скорочень плода та відповідність розмірів ембріона розмірам плідного яйця. У 6 (21,4\%) осіб діагностована субхоріальна гематома.

На момент надходження жінок до гінекологічного відділення оцінка болю за даними ЦРШ становила 3,0土0,32 (95\% ДІ 2-4). Протягом 7 днів терапії натуральним мікронізованим прогестероном біль зник у 26 з 28 пацієнток - 92,9\% (95\% ДІ 79,9-99,4). Кров'янисті виділення спостерігалися в 15 (53,6\%) осіб при надходженні до стаціонару. Через 7 днів лікування вони зникли в 14 пацієнток, що становило 93,3\% (95\% ДІ 73,7-100). Тривалість лікування до досягнення клінічного ефекту становила 5,0土0,37 (95\% ДІ 46) дня. В однієї пацієнтки 3 тяжким клінічним перебігом, яка отримувала терапію препаратом натурального мікронізованого прогестерону в дозі 600 мг на добу та мала генотип CC за SNP PGR rs590688, загроза вагітності завершилась викиднем.

Середній рівень прогестерону в обстежених жінок при надходженні до стаціонару становив $27,5 \pm 2,0$ нг/мл. У динаміці лікування на 7-й день лікування проводилось визначення прогестерону, загальний рівень прогестерону становив $37,6 \pm 2,1$ нг/мл. При аналізі рівня прогестерону в сироватці крові в пацієнток розподіл значень у варіаційних рядах при першому визначенні та при другому через 7 днів не відрізнялися від нормального, $\mathrm{p} \geq 0,1$ за критерієм W ШапіроУілка. Дані представлені $\mathrm{M} \pm \mathrm{m}$. Отримані дані дослідження цілком відповідають референтним нормам для відповідних термінів вагітності. При порівнянні використовувався критерій Стьюдента для пов'язаних вибірок. Приріст прогестерону становив $37 \%(\mathrm{t}=7,42 ; \mathrm{p}<0,001)$.

Проводилось двічі (на момент надходження в клініку та через 7 днів) визначення кількісного вмісту прогестерон індукованого блокуючого фактора в сечі у вагітних з загрозливим абортом, адже саме зростання вмісту цього фактора асоціюється $з$ пролонгацією вагітності. При аналізі вмісту ПІБФ в сечі пацієнток розподіл значень у варіаційних рядах при першому визначенні та при другому через 7 днів відрізнялися від нормального, $\mathrm{p}<0,01$ за критерієм W Шапіро-Уілка. Дані представлені $\mathrm{Me} \pm \mathrm{m}$ (95\% ДI).

На момент початку терапії концентрація ПІБФ становила 28,8土1,5 (95\% ДІ 26,7-29,2) нг/мл, а на 7-й день терапії натуральним мікронізованим прогестероном його концентрація становила 29,4士0,1 (95\% ДІ 29,2-29,5) нг/мл. Для порівняння був використаний критерій Т-критерій Уілкоксона. Протягом 7 днів вміст ПІБФ зріс на 2\% $(\mathrm{T}-\mathrm{W}=15,0 ; \mathrm{p}<0,001)$.

У переважної більшості пацієнток - 27 (96,4\%), які виносили вагітність, спостерігалося збільшення рівня ПІБФ. Слід також зазначити, що в 1 (3,6\%) пацієнтки стався самовільний викидень на 9-й день лікування. Саме в цьому випадку спостерігалося зниження концентрації ПІБФ в сечі з 29,18 нг/мл на момент надходження до клініки до 28,58 нг/мл на 7-й день терапії.

Проведене дослідження щодо рівня ПІБФ підтверджує, що зростання рівня ПІБФ асоціюється зі збереженням вагітності, а зниження - 3 іi перериванням. Як відомо, антиабортивний протеїн ПІБФ з'являється в крові жінок з ранніх 
строків вагітності, концентрація його наростає, досягаючи максимуму до 40 тижня гестації i різко знижується після пологів. На сьогодні достатньо докладно відомий імунний механізм впливу ПІБФ. Він, насамперед, діє на NKклітини, модулює імунну відповідь у бік менш активних натуральних кілерів CD56 + CD16-, призводить до зміни балансу Th1/Th2 у бік продукції цитокінів лімфоцитами Th2 [8, 10]. Отже, завдяки ПІБФ формується імунологічна толерантність, гальмується синтез прозапальних Th1 цитокінів. Крім того, внаслідок ПІБФ збільшується синтез асиметричних антитіл, які теж забезпечують захист ембріона [6].

Проведено аналіз результатів вагітності у 27 обстежених пацієнток, у яких прогресувала вагітність. Визначено, що у 20 (74,1\%) жінок у подальшому ускладнень перебігу вагітності не було. 26 (96,3\%) жінок мали термінові фізіологічні пологи, в 1 (3,7\%) пацієнтки пологи були патологічними шляхом операції кесаревого розтину 3 приводу дистресу плода в I періоді пологів.

\section{ВИСНОВКИ}

1. Показана ефективність терапії жінок із загрозливим абортом препаратом натурального мікронізованого прогестерону, що розроблена на підставі клініко-генетичного підходу 3 урахуванням алельного поліморфізму гена рецептора прогестерону rs590688.

2. Доведене статистично значуще зростання (p $<0,001)$ прогестерон індукованого блокуючого фактора в сечі жінок із загрозливим абортом при лікуванні препаратом натурального мікронізованого прогестерону.

3. Дослідження прогестерон індукованого блокуючого фактора можна розглядати в якості додаткового лабораторного методу контролю терапії препаратом натурального мікронізованого прогестерону жінок із загрозливим абортом у профільних науково орієнтованих закладах охорони здоров'я.

\section{СПИСОК ЛІТЕРАТУРИ}

1. Вовк І.Б. Ранні репродуктивні втрати / І.Б. Вовк, Ю.П. Вдовиченко, О.В. Трохимович. - Київ, 2016. $-253 \mathrm{c}$.

2. Гнатко О.П. Ефективність прогестеронової терапії у жінок із загрозливим абортом залежно від поліморфізму гена рецептора прогестерону / О.П. Гнатко, О.С. Кривопустов // Буковин. мед. вісник. - 2017. - Т. 21, № 1 (81). - С. 44-48.

3. Гнатко О.П. Оцінка ефективності прогестеронової терапії загрозливого аборту на підставі клінікогенетичного підходу з урахуванням алельного поліморфізму гена рецептора прогестерону rs590688 / О. П. Гнатко, О. С. Кривопустов // Експерим. і клініч. медицина. - 2017. - № 1 (74). - С. 71-76.

4. Clark C. Progestin regulation of cellular proliferation / C. Clark, R. Sutherland // Endocrine. - 1990. N 11. - P. 266-301.

5. Dosiou C. Natural killer cells in pregnancy and recurrent pregnancy loss. Endocrine and immunologic perspectives / C. Dosiou, L. Giudice // Endocr Rev. 2005. - N 26. - P. 44-62.

6. Kelemen K. A progesterone-induced protein increases the synthesis of asymmetric antibodies /
K. Kelemen, I. Bognar // Cell Immunol. - 1996. Vol. 167. - P. 129-134.

7. Manuck T. A. Progesterone receptor polymorphisms and clinical response to 17-alpha-hydroxyprogesterone caproate / T. A. Manuck, Y. Lai, P. J. Meis // Am. J. Obstet. Gynecol. - 2011. - Vol. 205. - P. 135.

8. Raghupathy R. Progesterone-induced blocking factor (PIBF) modulates cytokine production by lymphocytes from women with recurrent miscarriage or preterm delivery / R. Raghupathy, E. Al-Mutawa, M. Al-Azemi // J Reprod Immunol. - 2009. - Vol. 80. - P. 91-99.

9. Romano A. The PROGINS polymorphism of the human progesterone receptor diminishes the response to progesterone / A. Romano, B. Delvoux, D. Fischer // J. Mol. Endocrinol. - 2007. - Vol. 38. - P. 331-350.

10. Szekeres-Bartho J. A progesterone-dependent immunomodulatory protein alters the Th1/Th2 balance / J. Szekeres-Bartho, T. Wegmann // J Reprod Immunol. 1996. - Vol. 31. - P. 81-95.

11. Wahabi H. Progestogen for treating threatened miscarriage / H. Wahabi, A. Abed // Cochrane Database Syst Rev. -2011 .

\section{REFERENCES}

1. Vovk IB, Vdovychenko YP, Trokhymovych OV. [Early reproductive loss]. Kyiv. 2016;253. Ukrainian.

2. Gnatko OP, Kryvopustov OS. [Threatened abortion treatment efficacy depending on progesterone receptor gene polymorphism]. Bukov. med. visn. 2017;21(1):44-8. Ukrainian.

3. Gnatko OP, Kryvopustov OS. [Effectiveness of evaluation of progesterone therapy in women with threa- tened abortion based on clinical approach and single nucleotide polymorphism progesterone gene receptor rs590688]. Eksperym. i klin. medytsyna. 2017;1:71-6. Ukrainian.

4. Clarke CL, Sutherland RL. Progestin regulation of cellular proliferation. Endocr Rev. 1990;11(2):266-301.

5. Dosiou C, Giudice LC. Natural killer cells in pregnancy and recurrent pregnancy loss: endocrine and immunologic perspectives. Endocr Rev. 2005;26(1):44-62. 
6. Kelemen K, Bognar I, Paal M, Szekeres-Bartho J. A progesterone-induced protein increases the synthesis of asymmetric antibodies. Cell Immunol. 1996;167(1):129-34.

7. Manuck TA, Lai Y, Meis PJ, Dombrowski MP, Sibai B, Spong CY, et al. Progesterone receptor polymorphisms and clinical response to 17-alpha-hydroxyprogesterone caproate. Am J Obstet Gynecol. 2011;205(2):135.e1-9.

8. Raghupathy R, Al-Mutawa E, Al-Azemi M, Makhseed M, Azizieh F, Szekeres-Bartho J. Progesterone-induced blocking factor (PIBF) modulates cytokine production by lymphocytes from women with recurrent miscarriage or preterm delivery. J Reprod Immunol. 2009;80(1/2):91-9.

9. Romano A, Delvoux B, Fischer DC, Groothuis P. The PROGINS polymorphism of the human progesterone receptor diminishes the response to progesterone. J Mol Endocrinol. 2007;38(1/2):331-50.

10. Szekeres-Bartho J, Wegmann TG. A progesterone-dependent immunomodulatory protein alters the Th1/Th2 balance. J Reprod Immunol. 1996;31(1/2):81-95.

11. Wahabi HA, Abed Althagafi NF, Elawad M, Al Zeidan RA. Progestogen for treating threatened miscarriage. Cochrane Database Syst Rev. 2011;16(3):CD005943.

Стаття надійшла до редакції 18.04.2017

УДК 616.311.2-002-031.81-036-08

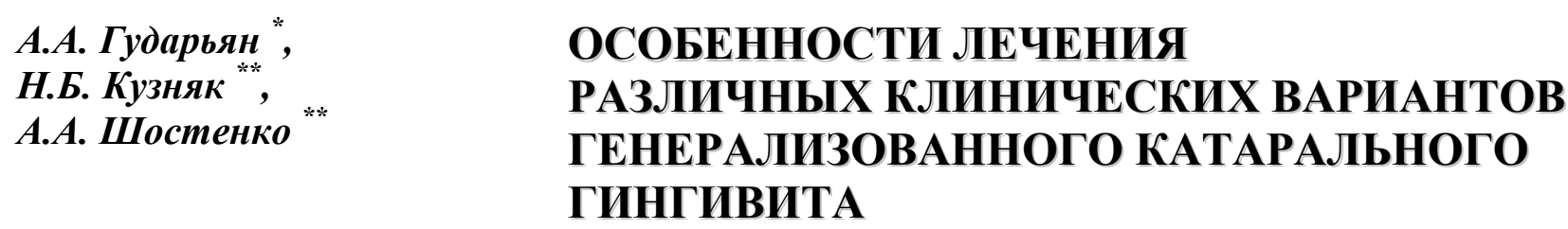

ГУ «Днепропетровская медицинская академия МЗ Украины» *

кафедра хирургической стоматологии, имплантологии и пародонтологии

(зав. - к. мед. н. Н.Г. Идашкина)

ул. Вернадского, 9, Днепр, 49044, Украина

ГУ «Буковинский государственньій медииинский университет» **

кафедра хирургической стоматологии

(зав. - к. мед. н. Н.Б. Кузняк)

Театральная пл., 2, Черновцьь, 58002, Украина

SE «Dnipropetrovsk medical academy of Health Ministry of Ukraine» *

Oral surgery, implantology and periodontology department

Vernadsky str., 9, Dnipro, 49044, Ukraine

e-mail: gudaryan@list.ru

SE «Bukovinian state medical university» **

Department of surgical dentistry

Theatralna sq., 2, Chernivtsi, 58002, Ukraine

e-mail: office@bsmu.edu.ua

Ключевые слова: генерализованный пародонтит, катаральный гингивит, микробиоченоз

Key words: generalized periodontitis, catarrhal gingivitis, microbiocenosis

Реферат. Особливості лікування різних клінічних варіантів генералізованого катарального гінгівіту. Гудар'ян О.О., Кузняк Н.Б., Шостенко А.А. У статті представлені результати комплексного лікування 82 хворих на генералізований катаральний гінгівіт на стадіі хронічного перебігу та загострення шляхом використання науково обтрунтованих програм етапного застосування професійних гігієнічних заходів, засобів антибактеріальної дії й імунокорегуючої терапії. Проведене етапне лікування генералізованого катарального гінгівіту сприяє швидкій елімінації можливих збудників захворювання, забезпечує усунення дефіциту місцевого гуморального імунітету, дисбалансу в циттокіновій системі, приводить до ліквідації запальних явищ в яснах у 93,3\% хворих з хронічним перебігом і в 96,3\% пацієнтів у період загострення захворювання. 